\title{
EFFECT OF USING SOME BIOLOGICAL PRODUCTS OF (NIGELLA SATIVA L.) ON IMPROVING CUCUMBER PRODUCTIVITY AND THE MICROBIAL ACTIVITY ASSOCIATED WITH PLANT GROWTH
}

\author{
El-Sayed, Mahmoud A.M. ${ }^{* 1}$ and Mohamed R. Hafez ${ }^{2}$ \\ ${ }^{1}$ Department of Soil Fertility and Microbiology, Desert Research \\ Center, El-Matareya, Cairo, Egypt \\ ${ }^{2}$ Department of Plant Production, Desert Research Center, El- \\ Matareya, Cairo, Egypt \\ *E-mail: mahalyed@yahoo.com, mahalyeg30@gmail.com
}

$\mathrm{T}$ wo field experiments were conducted to study the effect of black cumin (Nigella sativa L.) seed oil and seed cake on cucumber productivity (Prince cv.) and associated microorganisms. Seed cake was applied as soil addition before transplanting at rates of 0,5 , and 10 g per plant, while seed oil in $0,0.5,1$ and $1.5 \%$ solutions was applied as foliar application three times every 10 days beginning within 30 days of transplanting. Plants receiving the highest levels of seed cake $(10 \mathrm{~g})$ and seed oil $(1.5 \%)$ showed high density of total bacterial counts; Azotobacter chroococcum, Azospirillum brasilense and Bacillus megaterium, and high rates of $\mathrm{CO}_{2}$ evolution. However, the same treatments gave the lowest density of total fungal counts, including some pathogenic fungi (Fusarium, Rhizopus and Aspergillus niger). Both soil amendment and foliar application improved the growth characters of the cucumber, including the percentage of stand, the number of branches, plant height, the number of flowers and total chlorophyll as well as, the yield and fruit size.

Keywords: cucumber, biological products, Nigella sativa, microbial activity, growth, productivity

Cucumber (Cucumis sativus L.) is a widely cultivated plant in the gourd family Cucurbitaceae. The plant has a creeping vine, which bears cylindrical edible fruits. It could be cultivated year-round in desert lands by employing open field and green houses. Cucumber plants are susceptible to fungal diseases. 
Organic fertilization is a very important technique in this respect. Significant attentions have been paid by both growers and agricultural authorities to replace synthetic chemical fertilizers with natural organic fertilizers, which appear to be safe for the environment and improve soil fertility (David, 2002).

Also, plant extracts have been demonstrated to increase the productivity of tomato (plant length, leaf area, the number of branches, fresh and dry weight/plant and chlorophyll content) as well as the number of flowers and fruits (El-Dougdoug et al., 2007). Powdery mildew (PM) of cucumber was reduced from 52 to $7.7 \%$ for plants treated with $0.5 \%$ black seed oil (BSO), to $18.6 \%$ for plants treated with rape seed oil, and to $20 \%$ for plants treated with paraffin oil. Therefore, it is important to give more attention to BSO and other plant oils as an alternative disease control method in organic food production (Hafez, 2008). The use of BSO reduced PM disease by about $52 \%$.

The antifungal activity of essential oil of black cumin plants in combination with biocontrol bacteria Azotobacter and/or Bacillus megaterium and $\mathrm{N}$-fertilizer were examined against four phytopathogenic fungi (El-Sayed, 2006). Also, Thoppil et al. (1998) studied the activity of essential oils from four varieties of Nigella sativa against Fusarium semeticum, Aspergillus niger and Rhizopus stolonifer. They observed that all essential oils exhibited activity; the essential oil from Basilicum var. purpurascens was the most potent.

The obtained data also revealed that plant treated with mixed inoculants of Azotobacter chroococcum and Bacillus megaterium in the presence of half dose of inorganic $\mathrm{N}$-fertilizer allowed essential oils to have more inhibitory effect against the tested plant pathogenic fungi when compared with addition of full dose of $\mathrm{N}$-fertilizer in combination with separate inoculation. This result was observed in the two seasons for all treatments (El-Sayed, 2006).

Powdery mildew disease is one of the most serious plant diseases, causing large yield losses in a number of crops (Kiss, 2003). The disease affects the leaves, stems and fruits of cucumber (Cucumis sativus L.) grown in greenhouses and in the field (Bettiol et al., 2008). Powdery mildew of cucumber is one of the most common foliage diseases, attacking cucumber plants in Egypt and other countries (Harfoush and Salama, 1992; Mosa, 1997; Reuveni et al., 1997 and Verhaar et al., 1997). Using water extract of black cumin $(3.0 \%)$ led to elimination of TYLCV and produced virus-free tomato by tissue culture technique.

The main objective of the present work was to improve growth, yield and quality of cucumber under North Sinai conditions by addition of seed cake of Nigella sativa to the soil and by foliar spray with seed oil. It is also 
speculated that these treatments may reduce fungal infection, release nutrients to plant, and stimulate $\mathrm{CO}_{2}$ evolution.

\section{MATERIALS AND METHODS}

This study was carried out in the experimental farm of the Desert Research Center at El Sheikh Zowayed area, North Sinai Governorate, during the two summer growing seasons of 2009 and 2010.

Products from Nigella sativa (seed cake and seed oil) were produced under bioorganic agricultural conditions. The results of chemical analysis of seed cake and seed oil are given in table $(1 \& 2)$. Prince $\mathrm{cv}$. seeds were sown in early or mid-April. The transplanting date was 25 days from sowing.

Table (1). Physical and chemical properties of essential oils of $N$. sativa untreated (A) and treated with $A$. chroococcum and $B$. megaterium (B).

\begin{tabular}{|c|c|c|c|c|c|}
\hline \multicolumn{6}{|c|}{ Nigella sativa seed oils (\%) } \\
\hline Fractions & $\mathbf{A}$ & $\mathbf{B}$ & Fractions & $\mathbf{A}$ & $\mathbf{B}$ \\
\hline $\begin{array}{l}\text { Acidity \% (as } \\
\text { oleic acid) }\end{array}$ & $3-35$ & $2-95$ & $\alpha$ - Thujene & 1.60 & 3.68 \\
\hline $\begin{array}{l}\text { Peroxide value } \\
\text { (m-equiv.O } \mathrm{O}_{2} / \mathrm{kg} \\
\text { sample) }\end{array}$ & 48.33 & 29.83 & $\alpha$ - pinene & 0.87 & 0.84 \\
\hline $\begin{array}{l}\text { Iodine value } \\
\text { (Hanus) }\end{array}$ & 130.40 & 130.41 & Sapinene & 0.87 & 0.84 \\
\hline Color units & & & B-pinene & 2.50 & 4.18 \\
\hline Yellow & 35.00 & 35.00 & p- cymene & 46.90 & 50.15 \\
\hline Red & 17.30 & 17.30 & d- limonene & 2.19 & 2.25 \\
\hline Blue & 11.00 & 11.00 & Longifolene & 3.78 & 4.88 \\
\hline Fatty acids \% & & & Longipinene & 1.17 & 1.22 \\
\hline $\begin{array}{l}\text { Palmitic acid } \\
\text { (C16:0) }\end{array}$ & 13.31 & 13.25 & 4-Terpineol & 3.15 & 2.43 \\
\hline $\begin{array}{l}\text { Stearic acid (C } \\
18: 0)\end{array}$ & 1.80 & 1.32 & Thymoquinone & 28.70 & 11.87 \\
\hline Oleic acid (C 18:1) & 25.21 & 25.96 & Carvacrol & 0.00 & 0.43 \\
\hline $\begin{array}{l}\text { Linoleic acid (C } \\
\text { 18:2) }\end{array}$ & 59.37 & 59.47 & Total & 97.52 & 97.37 \\
\hline $\begin{array}{l}\text { Linolenic acid } \\
(18: 3 n-2)\end{array}$ & 0.31 & 0.00 & & & \\
\hline Total faty acids \% & 100 & 100 & & & \\
\hline
\end{tabular}

The experiment consisted of two factors: Soil application by adding some outputs of Nigella sativa (seed cake) with different doses $(0,5$ and 10 g seed cake /plant) one week after transplanting, and by spraying solutions 
containing different concentrations $(0,0.5,1$ and $1.5 \%)$ of oil extracted from Nigella sativa seed on the vegetative parts of the plant three times every ten days, the first spray after 30 days from transplanting.

Table (2). Physical and chemical properties of seed cake of $N$. sativa.

\begin{tabular}{cccccccc}
\hline \multicolumn{10}{c}{ Amino acids } \\
\hline $\begin{array}{c}\text { Essential Amino acids } \\
\text { (\%) }\end{array}$ & $\begin{array}{c}\text { Non-Essential } \\
\text { Amino acids (\%) }\end{array}$ & $\begin{array}{c}\text { Macronutrients } \\
\text { (\%) }\end{array}$ & $\begin{array}{c}\text { Micronutrients } \\
\text { (ppm) }\end{array}$ \\
\hline Threonine & 3.56 & Aspartic & 2.82 & $\mathbf{P}$ & 0.88 & $\mathbf{F e}$ & 413 \\
Valine & 4.46 & Serine & 3.67 & $\mathbf{M g}$ & 0.71 & $\mathbf{M n}$ & 40 \\
Methionine & 4.98 & Proline & 1.69 & $\mathbf{K}$ & 0.58 & $\mathbf{Z}$ & 80 \\
Isoleucine & 3.63 & Glycine & 10.39 & $\mathbf{C a}$ & 0.27 & & \\
Leucine & 4.44 & Alanine & 10.92 & $\mathbf{N}$ & 0.19 & & \\
Phnylalanine & 3.71 & Cystine & 0.036 & & & & \\
Lysine & 4.35 & Tyrosine & 0.025 & & & & \\
Arginine & 2.06 & Glutamic & 21.60 & & & & \\
Histidine & 2.90 & & & & & & \\
\hline
\end{tabular}

A split plots design with three replicates was used. The seed cake concentrations were assigned in the main plots, whereas the foliar spray by seed oil treatments were distributed in sub plots.

The experiment included 36 experimental units, 3 seed cake $\times 4$ foliar spray treatments $\times 3$ replicates. The experimental plot area was $10.5 \mathrm{~m}^{2}$; plant distance was $50 \mathrm{~cm}$ apart. The analysis of soil and irrigation water was performed according to Jackson (1958), Piper (1950) and Richards (1954), respectively, and are presented in tables (3, $4 \& 5)$. Determination of antimicrobial activity of extracted oil was studied according to Jacobs and Gerstein (1960).

A drip irrigation system was used. The length of line was $10.5 \mathrm{~m}$, and the width between lines was $1 \mathrm{~m}$.

Seed cake was added to soil one week after transplanting. Cucumber plants were sprayed three times with an aqueous solution of seed oil during each growing season. The first spray was performed after 30 days from transplanting, whereas, the second was applied three times every 10 days then 30 days. All replicates received similar agricultural practices with regard to cultivation, fertilization, irrigation, and pest disease control.

Chicken manure stable compost was used as fertilizers at $20 \mathrm{~m}^{3}$ per feddan, $100 \mathrm{~kg}$ calcium super phosphate per feddan and $100 \mathrm{~kg}$ agricultural sulfur before planting. Ammonium sulfate at $300 \mathrm{~kg}$, potassium sulfate at $150 \mathrm{~kg}$ and $15 \mathrm{~kg}$ phosphoric acid were divided into small quantities and added weekly in drip irrigation system during the growing seasons. 
Table (3). Chemical analysis of the soil at North Sinai Research Station-El Sheikh Zowayed area.

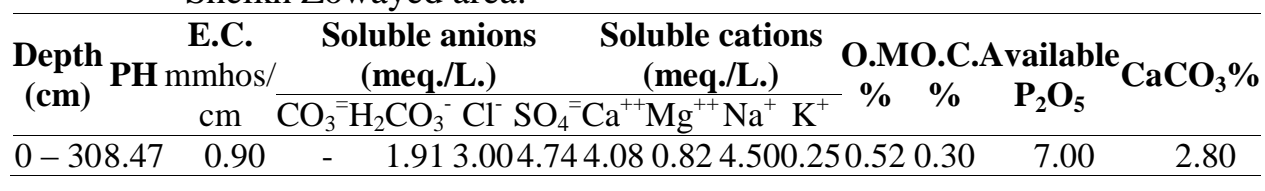

Table (4). Particle size distribution of the soil at North Sinai Research Station - El Sheikh Zowayed area.

\begin{tabular}{ccccc}
\hline $\begin{array}{c}\text { Fine sand } \\
(\boldsymbol{\%})\end{array}$ & $\begin{array}{c}\text { Coarse sand } \\
(\boldsymbol{\%})\end{array}$ & $\begin{array}{c}\text { Silt } \\
(\boldsymbol{\%})\end{array}$ & $\begin{array}{c}\text { Clay } \\
(\boldsymbol{\%})\end{array}$ & Texture \\
\hline 31.96 & 58.16 & 7.43 & 2.25 & Sandy \\
\hline
\end{tabular}

Table (5). Chemical analysis of irrigation water at North Sinai Research Station -El Sheikh Zowayed area.

\begin{tabular}{|c|c|c|c|c|c|c|c|}
\hline \multirow[t]{2}{*}{ PH } & EC. & \multicolumn{2}{|c|}{$\begin{array}{c}\text { Soluble Anions } \\
(\text { meq./L) }\end{array}$} & \multicolumn{4}{|c|}{$\begin{array}{c}\text { Soluble cations } \\
\text { (meq./L) }\end{array}$} \\
\hline & ppmmmhos & $\mathrm{o}_{3}{ }^{\circ} \mathrm{H}_{2} \mathrm{CO}_{3}{ }^{-} \mathrm{Cl}$ & $\mathrm{SO}_{4}{ }^{=}$ & $\mathbf{C a}^{++}$ & $\mathbf{M g}^{+}$ & $\mathrm{Na}^{+}$ & $\mathbf{K}^{+}$ \\
\hline 7. & 3.892 & $\begin{array}{ll}2.72 & 8.7 \\
\end{array}$ & $\begin{array}{ll}7 & 33.38 \\
\end{array}$ & 7.0 & 10.5 & 25.3 & 2.01 \\
\hline
\end{tabular}

\section{Microbiological Determinations}

Rhizosphere soil samples were collected from soil after germination at 30, 60 and 90 days from transplanting to estimate the number of different microbial types and total microbial counts on Bunt and Rovira agar medium (Bunt and Rovira, 1955), total fungal counts on Martin's medium (Allen, 1959), Azotobacter spp. on nitrogen deficient medium (Abd El Malek and Ishac, 1968), Azospirillum spp. on semi-solid malate medium (Dobereiner, 1978). Bacillus spp. was quantified on modified Bunt and Rovira medium (Abd El-Hafez, 1966) using the dilution frequency method. $\mathrm{CO}_{2}$ evolution was measured according to Pramer and Schmidt (1994).

\section{Determination of Antimicrobial Activity of Extracted Oil}

The effect of the extracted oil of black cumin with concentrations of $500,750,1000$ and $1250 \mathrm{ppm}$ on the growth of pathogenic fungi was studied by measuring the inhibition zone and minimum inhibitory concentration as described by Sleigh and Timburg (1981).

Disc diffusion method was used for determining the antimicrobial activity of extracted oil against the pathogenic fungi (Aspergillus niger, Fusarium semeticum and Rhizopus stolonifer) as described by Jacobs and Gerstein (1960). 


\section{Plant Parameters}

Five plants were randomly taken from each experimental plot after 50 days from transplanting. Data on vegetative growth, fruit yield, and fruit quality were recorded as following:

\subsection{Vegetative growth}

1. Percentage of stand

2. Fresh and dry weight $(\mathrm{g})$

3. Plant length $(\mathrm{cm})$

4. Total chlorophyll using chlorophyll meter according to A.O.A.C. (1990)

5. Number of flowers/ plant

\subsection{Total yield and fruit quality}

During each experimental season all fruits from each plot were harvested ten times and total fruits were collected. The yields per plant and per plot as well as per feddan were then calculated. The data that have been taken were as following:

1. Fruit length $(\mathrm{cm})$

2. Average fruit weight $(\mathrm{g})$

3. Fruit diameters $(\mathrm{mm})$

4. Total yield (g/plant or ton/fed)

5. Dry weight per fruit $(\mathrm{g})$

\section{Statistical Analysis}

Data were analyzed using ANOVA according to Snedecor and Cochran (1989).

\section{RESULTS AND DISCUSSION}

\section{Effect of Using Some Biological Products of Nigella sativa L. on Total Counts of Bacteria and Fungi}

Data presented in table (6) show the effect of using seed cake and seed oil of Nigella at different levels on total bacterial counts during two seasons and at different stages of plant growth. With respect to adding seed oil at different rates, data show that increasing seed oil addition in the absence of seed cake increased total bacterial counts for all stages of plant growth.

In the presence of seed cake at $5 \mathrm{~g}$ with or without seed oil, total count also increased more than in case of seed cake absence. Increasing seed cake to $10 \mathrm{~g} /$ plant with adding seed oil levels at $1.5 \%$ gave the highest density of total bacterial counts at different stages of plant growth, reaching 99, 277, $259 \times 10^{5} \mathrm{CFU} / \mathrm{g}$ dry soil for 30, 60 and 90 days for the first season and 105, $297,265 \times 10^{5}$ CFU/g dry soil at the same stages during the second season.

Egyptian J. Desert Res., 62/63, 21-37 (2012/2013) 
Table (6). Effect of using some biological products of Nigella sativa L. on total bacterial counts during 2009/2010 seasons.

\begin{tabular}{|c|c|c|c|c|c|c|c|c|c|c|}
\hline \multirow{3}{*}{$\begin{array}{l}\text { Seeds } \\
\text { dregs }\end{array}$} & \multirow{3}{*}{ eeds oil } & \multicolumn{6}{|c|}{ Total Bacterial counts (Counts $\times 10^{5} \mathrm{CFU} / \mathrm{g}$ dry soil) } & \multirow{2}{*}{\multicolumn{3}{|c|}{$\begin{array}{l}\text { Average as total } \\
\text { microbial counts }\end{array}$}} \\
\hline & & \multicolumn{3}{|c|}{ Season 1} & \multicolumn{3}{|c|}{ Season 2} & & & \\
\hline & & 30 day & 60 day & 90 day & 30 day & 60 day & 90 day & 30 day & 60 day & 90 day \\
\hline \multirow{4}{*}{ Control } & Zero & 32 & 39 & 36 & 35 & 47 & 40 & 34 & 43 & 38 \\
\hline & $0.5 \%$ & 39 & 48 & 46 & 44 & 56 & 50 & 42 & 52 & 48 \\
\hline & $1 \%$ & 45 & 65 & 62 & 49 & 77 & 62 & 47 & 71 & 62 \\
\hline & $1.5 \%$ & 48 & 67 & 65 & 52 & 80 & 66 & 50 & 74 & 66 \\
\hline \multirow{4}{*}{$5 \mathrm{~g}$} & Zero & 37 & 70 & 65 & 50 & 90 & 81 & 44 & 80 & 73 \\
\hline & $0.5 \%$ & 49 & 99 & 89 & 57 & 115 & 105 & 53 & 107 & 97 \\
\hline & $1 \%$ & 60 & 131 & 110 & 69 & 135 & 120 & 65 & 133 & 115 \\
\hline & $1.5 \%$ & 65 & 135 & 115 & 71 & 140 & 127 & 68 & 138 & 121 \\
\hline \multirow{4}{*}{$10 \mathrm{~g}$} & Zero & 55 & 121 & 97 & 61 & 139 & 120 & 58 & 130 & 109 \\
\hline & $0.5 \%$ & 83 & 215 & 210 & 89 & 256 & 227 & 86 & 236 & 219 \\
\hline & $1 \%$ & 95 & 269 & 255 & 101 & 295 & 262 & 98 & 282 & 259 \\
\hline & $1.5 \%$ & 99 & 277 & 259 & 105 & 297 & 265 & 102 & 287 & 262 \\
\hline
\end{tabular}

*Initial total bacterial count was $65 \times 10^{2}(\mathrm{CFU} / \mathrm{g}$ dry soil).

While the results presented in table (7) show the impact of using seed cake and seed oil of Nigella at different levels on total fungal counts during the two seasons and at different stages of plant growth. With respect to adding seed oil at different rates, data show that by increasing seed oil addition, in the absence of seed cake, fungi decreased at different stages of plant growth during two seasons.

Table (7). Effect of using some biological products of Nigella sativa L. on total fungal counts during 2009/2010 seasons.

\begin{tabular}{|c|c|c|c|c|c|c|c|c|c|c|}
\hline \multirow{3}{*}{$\begin{array}{l}\text { Seeds } \\
\text { dregs }\end{array}$} & \multirow[t]{3}{*}{ eds oil } & \multicolumn{6}{|c|}{$\begin{array}{l}\text { Total fungal counts (Counts } \times 10^{2} \text { CFU/g dry } \\
\text { soil) }\end{array}$} & \multirow{2}{*}{\multicolumn{3}{|c|}{$\begin{array}{l}\text { Average as total } \\
\text { fungal counts }\end{array}$}} \\
\hline & & \multicolumn{3}{|c|}{ Season 1} & \multicolumn{3}{|c|}{ Season 2} & & & \\
\hline & & $30 \mathrm{da}$ & $60 \mathrm{~d}$ & 90 day & 30 day & 60 day & 90 day & 30 day & 60 day & 90 day \\
\hline \multirow{4}{*}{ Control } & Zero & 70 & 80 & 84 & 60 & 70 & 80 & 65.0 & 75.0 & 82.0 \\
\hline & $0.5 \%$ & 47 & 40 & 36 & 50 & 40 & 33 & 48.5 & 40.0 & 34.5 \\
\hline & $1 \%$ & 38 & 32 & 28 & 40 & 35 & 31 & 39.0 & 33.5 & 29.5 \\
\hline & $1.5 \%$ & 33 & 22 & 20 & 37 & 31 & 28 & 35.0 & 26.5 & 24.0 \\
\hline \multirow{4}{*}{$5 \mathrm{~g}$} & Zero & 35 & 29 & 28 & 37 & 31 & 29 & 36.0 & 30.0 & 28.5 \\
\hline & $0.5 \%$ & 23 & 18 & 16 & 25 & 20 & 15 & 24.0 & 19.0 & 15.5 \\
\hline & $1 \%$ & 20 & 16 & 14 & 22 & 17 & 13 & 21.0 & 16.5 & 13.5 \\
\hline & $1.5 \%$ & 16 & 13 & 11 & 15 & 12 & 10 & 15.5 & 12.5 & 10.5 \\
\hline \multirow{4}{*}{$10 \mathrm{~g}$} & Zero & 30 & 22 & 17 & 31 & 28 & 22 & 30.5 & 25.0 & 19.5 \\
\hline & $0.5 \%$ & 16 & 14 & 11 & 22 & 16 & 11 & 19.0 & 15.0 & 11.0 \\
\hline & $1 \%$ & 13 & 10 & 8 & 14 & 11 & 9 & 13.5 & 10.5 & 8.5 \\
\hline & $1.5 \%$ & 11 & 8 & 5 & 10 & 5 & 3 & 10.5 & 6.5 & 4.0 \\
\hline
\end{tabular}

*Initial total fungal count was $90 \times 10^{2}(\mathrm{CFU} / \mathrm{g}$ dry soil).

Egyptian J. Desert Res., 62/63, 21-37 (2012/2013) 
In the presence of seed cake at $5 \mathrm{~g}$ with or without seed oil, total counts of fungi also decreased more than in case of absence of seed cake. Increasing seed cake to $10 \mathrm{~g} / \mathrm{plant}$ with adding seed oil levels at $1.5 \%$ gave the lowest density of total fungal counts at different stages of plant growth and during the two growing seasons, reaching $11,8,5 \times 10^{2} \mathrm{CFU} / \mathrm{g}$ dry soil for 30, 60 and 90 days for the first season and to $10,5,3 \times 10^{2} \mathrm{CFU} / \mathrm{g}$ dry soil at the same stages during the second season.

The recorded data indicated that control treatment without using any biological products gave higher growth of fungi. This may be due to the production of siderphore compounds, which inhibit fungal spore germination via causing unavailability of nutrients (Jagnow, 1991) or due to the lyses of chitinaceous cell walls of pathogenic fungi by specific enzymes produced by bacteria (Nelson et al., 1986).

\section{Effect of Using Some Biological Products of Nigella sativa L. on Azotobacter spp. and Azospirillum spp. Densities}

Data in tables (8 and 9) show that when seed oil was applied in the absence of seed cake, the numbers of Azotobacter spp. and Azospirillum spp. increased at different stages of plant growth during the two seasons. In the presence of seed cake at $5 \mathrm{~g}$ with or without seed oil, Azotobacter spp. and Azospirillum spp. also increased more in case of seed cake absence.

Table (8). Effect of using some biological products of Nigella sativa $\mathrm{L}$. on Azotobacter densities during 2009/2010 seasons.

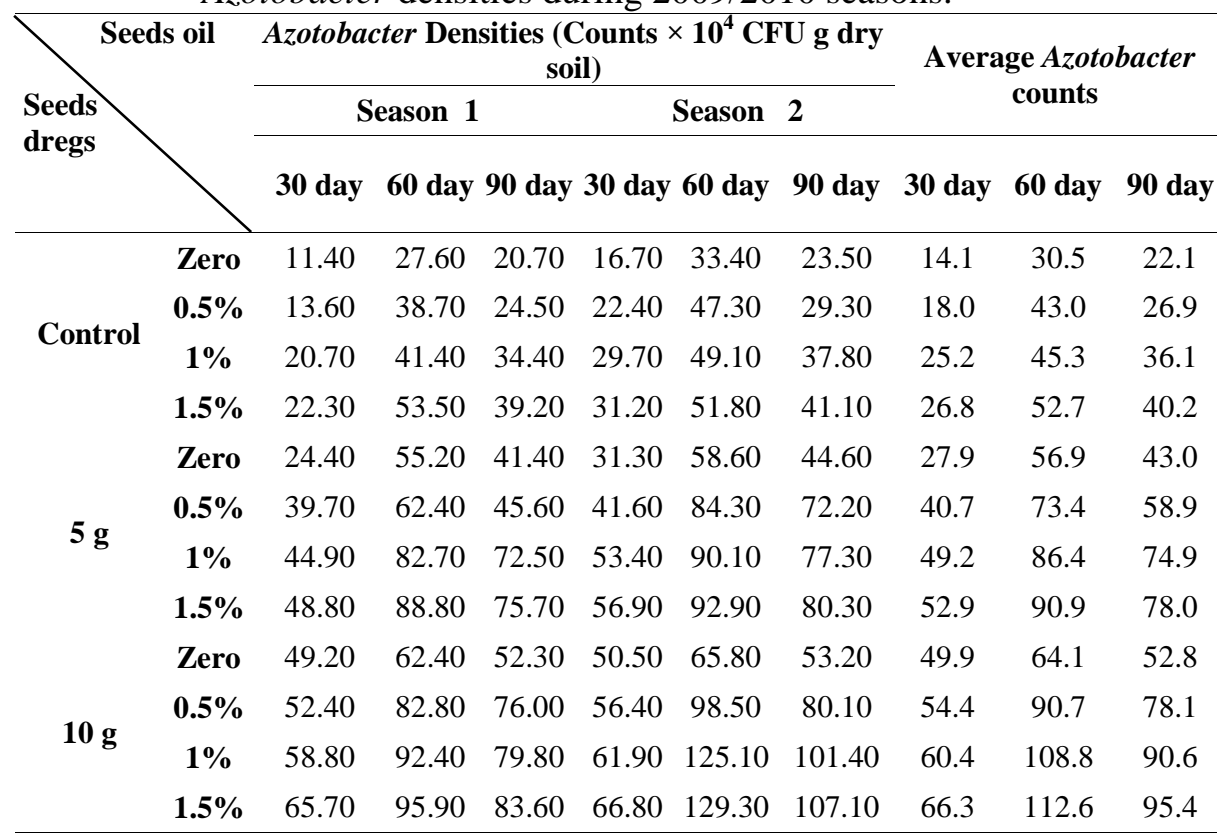

Egyptian J. Desert Res., 62/63, 21-37 (2012/2013) 
*Initial Azotobacter densities was $30 \times 10^{2}$ (CFU/g dry soil).

Table (9). Effect of using some biological products of Nigella sativa L. on Azospirillum densities during 2009/ 2010 seasons.

\begin{tabular}{|c|c|c|c|c|c|c|c|c|c|c|}
\hline \multirow{3}{*}{\multicolumn{2}{|c|}{ Seeds oil }} & \multirow{2}{*}{\multicolumn{6}{|c|}{$\begin{array}{c}\text { Azospirillum Densities (Counts } \times 10^{4} \text { CFU } \\
\text { g dry soil) }\end{array}$}} & \multicolumn{3}{|c|}{ Average } \\
\hline & & & & & & & & & & \\
\hline & & 30 day & $\begin{array}{r}60 \\
\text { day }\end{array}$ & $\begin{array}{r}90 \\
\text { day }\end{array}$ & $\begin{array}{r}30 \\
\text { day }\end{array}$ & $\begin{array}{r}60 \\
\text { day }\end{array}$ & $\begin{array}{r}90 \\
\text { day }\end{array}$ & $\begin{array}{r}30 \\
\text { day }\end{array}$ & $\begin{array}{r}60 \\
\text { day }\end{array}$ & $\begin{array}{r}90 \\
\text { day }\end{array}$ \\
\hline \multirow{4}{*}{ Control } & Zero & 14.7 & 18.6 & 15.0 & 15.0 & 21.0 & 18.6 & 14.9 & 19.8 & 16.8 \\
\hline & $0.5 \%$ & 17.3 & 24.0 & 22.0 & 21.0 & 28.0 & 23.9 & 19.2 & 26.0 & 23.0 \\
\hline & $1 \%$ & 21 & 28.0 & 24.5 & 22.0 & 34.0 & 28.0 & 21.5 & 31.0 & 26.3 \\
\hline & $1.5 \%$ & 23 & 34.0 & 28.0 & 24.5 & 36.0 & 30.5 & 24.2 & 35.0 & 29.3 \\
\hline \multirow{4}{*}{$5 \mathrm{~g}$} & Zero & 21.1 & 28.0 & 24.5 & 22.4 & 31.0 & 26.2 & 21.8 & 29.5 & 25.4 \\
\hline & $0.5 \%$ & 24.5 & 32.0 & 30.5 & 28.0 & 34.0 & 30.5 & 26.3 & 33.0 & 30.5 \\
\hline & $1 \%$ & 28.0 & 34.0 & 32.0 & 32.0 & 40.0 & 36.0 & 30.0 & 37.0 & 34.0 \\
\hline & $1.5 \%$ & & 3.0 & 34.0 & 34.0 & 41.0 & 39.0 & 32.3 & 42.0 & 36.5 \\
\hline \multirow{4}{*}{$10 \mathrm{~g}$} & Zero & 28 & 34.0 & 30.5 & 26.2 & 34.0 & 28.0 & 27.1 & 34.0 & 29.3 \\
\hline & $0.5 \%$ & 34.0 & 43.0 & 36.0 & 36.0 & 50.0 & 39.0 & 35.0 & 46.5 & 37.5 \\
\hline & $1 \%$ & 41.5 & 60.0 & 43.0 & 41.5 & 59.0 & 41.0 & 41.5 & 59.5 & 42.0 \\
\hline & $1.5 \%$ & 43.0 & 92.0 & 64.0 & 43.0 & 84.0 & 50.0 & 43.0 & 88.0 & 57.0 \\
\hline
\end{tabular}

*Initial Azospirilla Densities was $30 \times 10^{2}$ (CFU/g dry soil).

Increasing seed cake to $10 \mathrm{~g} /$ plant with adding seed oil gave the highest density of Azotobacter spp. \& Azospirillum spp. at different stages of plant growth, with the average densities reaching 66.3, 112.6 and $95.4 \times 10^{4}$ CFU/g dry soil for 30, 60 and 90 days for Azotobacter spp. and reaching 43, 88 and $57 \times 10^{4} \mathrm{CFU} / \mathrm{g}$ dry soil for Azospirillum spp. When plants have been treated with $10 \mathrm{~g}$ seed cake combined with foliar application with seed oil at $1.5 \%$, gave the highest density of Azotobacter spp. and Azospirillum spp. at different stages of plant growth, with the average of Azotobacter spp. and Azospirillum spp. densities reaching 66.3, 112.6, 95.4, 43.0, 88.0 and $57.0 \times 10^{4} \mathrm{CFU} / \mathrm{g}$ dry soil, respectively, for 30,60 and 90 days.

\section{Effect of Using Some Biological Products of Nigella sativa L. on Bacillus spp. Densities}

With respect to adding seed oil at different rates, data in table (10) show that increasing seed oil addition in the absence of seed cake increased Bacillus spp. densities at different stages of plant growth and during the two seasons.

In the presence of seed cake at $5 \mathrm{~g}$ with or without seed oil also increased Bacillus spp. densities more than observed in case of absence of seed cake. Increasing seed cake to $10 \mathrm{~g}$ /plant with the addition of $1.5 \%$ seed oil gave the highest density of Bacillus spp. at different stages of plant growth, with the average of Bacillus spp. densities reaching 98, 148 and 125 $\mathrm{x} 10^{4} \mathrm{CFU} / \mathrm{g}$ dry soil for 30,60 and 90 days. 
Table (10). Effect of using some biological products of Nigella sativa L. on Bacillus spp. densities during 2009/2010 seasons.

\begin{tabular}{|c|c|c|c|c|c|c|c|c|c|c|}
\hline \multirow{3}{*}{\multicolumn{2}{|c|}{ Seeds dregs }} & \multirow{2}{*}{\multicolumn{6}{|c|}{ 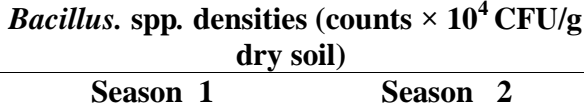 }} & \multirow{2}{*}{\multicolumn{3}{|c|}{$\begin{array}{l}\text { Average of Bacillus. } \\
\text { spp. counts }\end{array}$}} \\
\hline & & & & & & & & & & \\
\hline & & 30 day & 60 & 90 & 30 & 60 & 90 & 30 & 60 & 90 \\
\hline \multirow{4}{*}{ Control } & Zero & 33 & 38 & 35 & 35 & 46 & 37 & 34 & 42 & 36 \\
\hline & $0.5 \%$ & 36 & 41 & 38 & 40 & 50 & 42 & 38 & 46 & 40 \\
\hline & $1 \%$ & 39 & 44 & 40 & 45 & 55 & 49 & 42 & 50 & 45 \\
\hline & $1.5 \%$ & 42 & 49 & 44 & 50 & 63 & 55 & 46 & 56 & 50 \\
\hline \multirow{4}{*}{$5 \mathrm{~g}$} & Zero & 40 & 70 & 55 & 50 & 80 & 60 & 45 & 75 & 58 \\
\hline & $0.5 \%$ & 51 & 81 & 70 & 63 & 95 & 78 & 57 & 88 & 74 \\
\hline & $1 \%$ & 57 & 95 & 78 & 70 & 105 & 85 & 64 & 100 & 82 \\
\hline & $1.5 \%$ & 63 & 105 & 95 & 85 & 115 & 100 & 74 & 110 & 98 \\
\hline \multirow{4}{*}{$10 \mathrm{~g}$} & Zero & 55 & 80 & 65 & 70 & 95 & 80 & 63 & 88 & 73 \\
\hline & $0.5 \%$ & 64 & 95 & 85 & 90 & 150 & 105 & 77 & 123 & 95 \\
\hline & $1 \%$ & 71 & 105 & 90 & 100 & 160 & 120 & 86 & 133 & 105 \\
\hline & $1.5 \%$ & 80 & 115 & 105 & 115 & 180 & 145 & 98 & 148 & 125 \\
\hline
\end{tabular}

*Initial total Bacillus count was $35 \times 10^{2}$ (CFU/g dry soil).

\section{Effect of Using Some Biological Products of Nigella sativa $\mathrm{L}$. on $\mathrm{CO}_{2}$ Evolution}

Table (11) describes the effect of using seed cake and seed oil of Nigella at different levels of microbial activity through $\mathrm{CO}_{2}$ evolution $(\mu \mathrm{g} / \mathrm{g}$ dry soil / h) in the area of soil surrounding the roots of the plants during the two seasons and at different stages of plant growth.

Table (11). Effect of using some biological products of Nigella sativa L. on $\mathrm{CO}_{2}$ evolution ( $\mu \mathrm{g} / \mathrm{g}$ dry soil/h) during $2009 / 2010$ seasons.

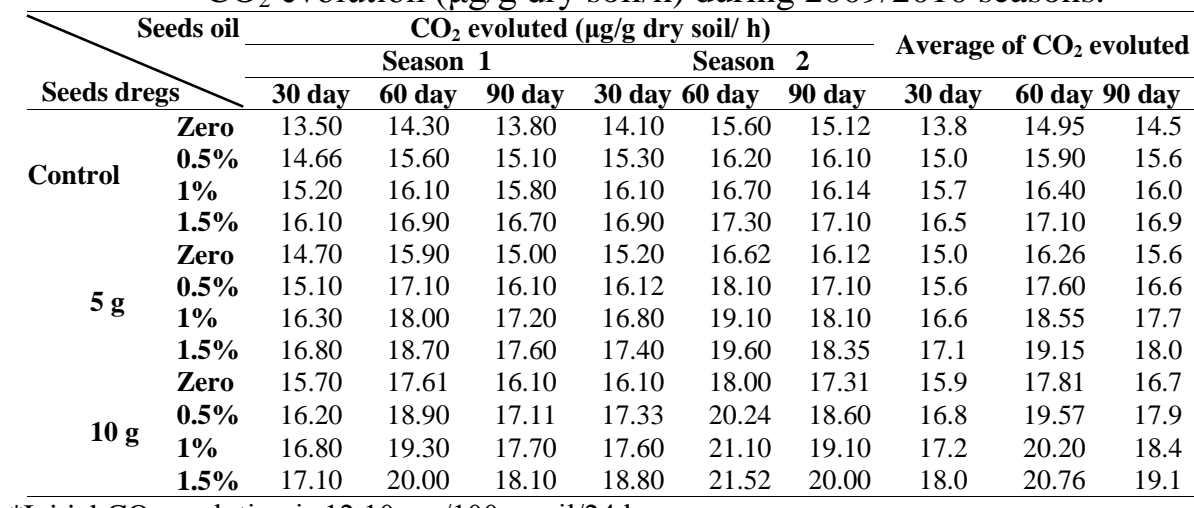

*Initial $\mathrm{CO}_{2}$ evolution is $12.10 \mu \mathrm{g} / 100 \mathrm{~g}$ soil $/ 24 \mathrm{~h}$.

With regard to adding seed oil at different rates, the data show that increasing seed oil addition in the absence of seed cake increased the rate of

Egyptian J. Desert Res., 62/63, 21-37 (2012/2013) 
$\mathrm{CO}_{2}$ evolution ( $\mu \mathrm{g} / \mathrm{g}$ dry soil $/ \mathrm{h}$ ) at different stages of plant growth and during two seasons.

In the presence of seed cake at $5 \mathrm{~g}$ with or without seed oil, the rate of soil $\mathrm{CO}_{2}$ evolution also increased ( $\mu \mathrm{g} / \mathrm{g}$ dry soil $/ \mathrm{h}$ ) compared to soils without seed cake. Increasing seed cake to $10 \mathrm{~g} /$ plant with adding oil seed gave the highest quantity of $\mathrm{CO}_{2}$ activity $(\mu \mathrm{g} / \mathrm{g}$ dry soil $/ \mathrm{h})$ at different stages of plant growth. The average of $\mathrm{CO}_{2}$ exchange $(\mu \mathrm{g} / \mathrm{g}$ dry soil $/ \mathrm{h})$ reached 18, 20.78, and 19.10 for 30, 60 and 90 days when plants were treated with $10 \mathrm{~g}$ seed cake combined with foliar application with seed oil at $1.5 \%$.

\section{Effect of Using Some Biological Products of Nigella sativa L. on Some Plant Pathogenic Fungi}

The results in table (12) and Fig. (1) show that using solutions with concentrations of 500, 750, 1000 and $1250 \mathrm{ppm}$ of oil from Nigella sativa seeds inhibited the growth of some pathogenic fungi to cucumber plant including Fusarium, Rhizopus and A. niger. The inhibition zones were the largest at concentrations of 1250 and $1000 \mathrm{ppm}$. The inhibition zones produced by concentrations of 750 and $500 \mathrm{ppm}$ were smaller but still significant compared to control treatments.

\section{Cucumber Growth and Yield Characteristics as Affected by Nigella sativa $\mathbf{L}$. Treatments \\ 6.1. Growth characteristics}

It is clear from results presented in table (13) that soil application with seed cake of Nigella sativa at $10 \mathrm{~g}$ produced a significant increase in vegetative growth characters, i.e., percentage of stand, plant height, number of flowers/plant, fresh weight/plant and total chlorophyll, except dry matter percentage, which has given the highest values in the two experimental seasons as compared with control treatment. The results were true in both growing seasons.

The effect of foliar spray treatments on growth parameters showed the highest value with Nigella sativa oil at $1.5 \%$ treatment when compared with the other tested treatments in both seasons, while the control treatment showed the lowest value in both seasons. This result suggests that powdery mildew of cucumber (Podosphaera xanthii) was reduced by spraying Nigella sativa oil, which is in agreement with Hafez (2008). The combination of soil amendment with seed cake with foliar spray of oil gave a significant improvement on all growth characters in both tested seasons. These results indicated the important role of Nigella sativa oil and seed cake in improving growth characteristics of cucumber plants. Also seed cake application alone has positive effect on plant growth by stimulating the growth of rhizosphere microorganisms, which are playing fundamental role in minerals uptake by 
plant. Regardless, the result agree with those obtained by Hassan and Vancura (1970) who detected that microbial products of Azotobacter chroococcum, Azospirillum brasilense, Bacillus megaterium had a positive effect on plant length and weight, due to excretion of some growth regulators as gibberellin like substances in microbial culture.

Table (12). Effect of using some biological products of Nigella sativa L. on some plant pathogenic fungi during 2009/2010 seasons.

\begin{tabular}{|c|c|c|c|c|c|c|c|c|}
\hline \multirow{2}{*}{\multicolumn{2}{|c|}{$\begin{array}{r}\text { Concentrations of } \\
\text { oil }(\mathrm{ppm})\end{array}$}} & \multicolumn{7}{|c|}{ Diameter of Inhibition zone $(\mathbf{c m})$} \\
\hline & & \multicolumn{3}{|c|}{ A } & \multicolumn{4}{|c|}{ B } \\
\hline Fungi & 500 & 750 & 1000 & 1250 & 500 & 750 & 1000 & 1250 \\
\hline Fusarium & 0.0 & 0.0 & 1.20 & 1.25 & 1.23 & 1.77 & 2.50 & 3.80 \\
\hline Rhizopus & 0.0 & 0.0 & 0.40 & 0.81 & 1.50 & 2.68 & 3.17 & 4.03 \\
\hline A. niger & 0.0 & 0.0 & 1.10 & 1.30 & 2.07 & 3.97 & 4.67 & 5.83 \\
\hline
\end{tabular}

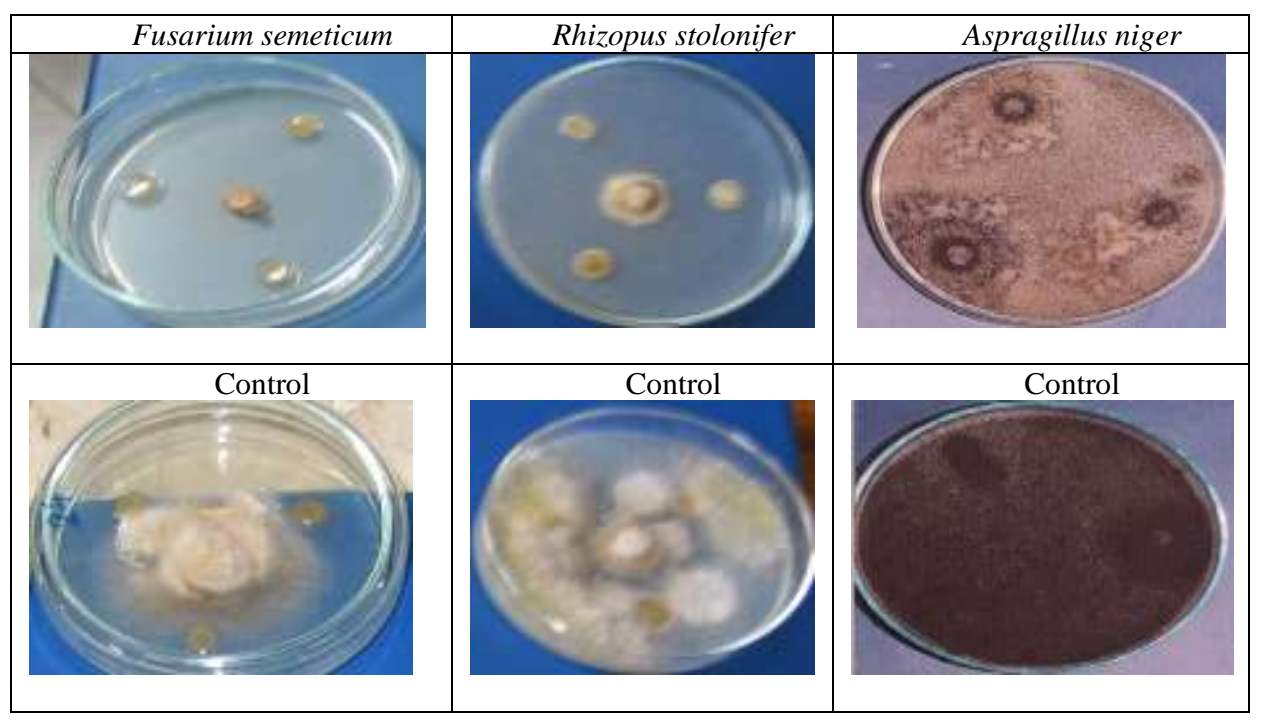

Fig. (1). Effect of using some biological products of Nigella sativa L. on some plant pathogenic fungi.

\subsection{Yield and its component}

It is evident from table (14) that seed cake gave significant increase in total yield and its components, i.e. fruit length, average fruit weight fruit diameter and total yield per plant (g) and per fed (ton). The highest values of yield and its components were obtained by application of seed cake at rate of $10 \mathrm{~g}$ around plant root, except dry matter (\%). Control treatment showed a significant increase in fruit dry matter $(\%)$ in both growing seasons. 
Foliar spray effect with Nigella sativa oil at $1.5 \%$ produced the highest value of fruit length, average fruit weight, fruit diameter, dry matter (\%) and total yield per plant and per feddan. These results may be due to the role of Nigella sativa oil in increasing cell division, as suggested by ElDougdoug et al. (2007).

The interaction treatment between seed cake at rate of $10 \mathrm{~g}$ per plant and Nigella sativa oil at $1.5 \%$ showed the highest values on total yield and its components, except the dry matter (\%) character. These results suggest a role of Nigella sativa oil and seed cake in reducing powdery mildew of cucumber and improving soil conditions around the root zone (Harfoush and Salama, 1992; Mosa, 1997; Reuveni et al., 1997 and Verhaar et al., 1997).

Table (13). Effect of using some biological products of (Nigella sativa L.) on growth characters of cucumber plant during 2009/2010 seasons.

\begin{tabular}{|c|c|c|c|c|c|c|c|c|c|c|c|c|c|}
\hline \multicolumn{2}{|c|}{ Treatments } & \multirow{2}{*}{\multicolumn{2}{|c|}{$\begin{array}{c}\text { Percentage of } \\
\text { stand }\end{array}$}} & \multirow{2}{*}{\multicolumn{2}{|c|}{$\begin{array}{c}\text { Fresh weight } \\
\text { g/plant }\end{array}$}} & \multirow{2}{*}{\multicolumn{2}{|c|}{$\begin{array}{l}\text { Plant length } \\
\text { (cm) }\end{array}$}} & \multirow{2}{*}{\multicolumn{2}{|c|}{$\begin{array}{c}\text { Number of } \\
\text { flowers/plant }\end{array}$}} & \multirow{2}{*}{\multicolumn{2}{|c|}{$\begin{array}{c}\text { Total } \\
\text { chlorophyll }\end{array}$}} & \multirow{2}{*}{\multicolumn{2}{|c|}{$\begin{array}{l}\text { Dry matter } \\
\text { (\%/plant) }\end{array}$}} \\
\hline \multirow{2}{*}{$\begin{array}{l}\text { Seeds } \\
\text { dregs }\end{array}$} & \multirow{2}{*}{$\begin{array}{c}\text { Seeds } \\
\text { oil }\end{array}$} & & & & & & & & & & & & \\
\hline & & S1 & $\mathbf{S 2}$ & S1 & $\mathbf{S 2}$ & S1 & $\mathbf{S 2}$ & S1 & $\mathbf{S 2}$ & S1 & $\mathbf{S 2}$ & S1 & $\mathbf{S 2}$ \\
\hline \multirow{4}{*}{ \{ontrol } & Zero & 32,33 & 30,67 & 127,67 & 210,33 & 67,00 & 113,00 & 4,67 & 8,67 & 25,00 & 30,33 & 26,83 & 28,90 \\
\hline & $0.5 \%$ & 34,33 & 32,33 & 167,67 & 244,67 & 75,00 & 128,67 & 12,33 & 18,00 & 26,77 & 34,67 & 61,03 & 63,13 \\
\hline & $1 \%$ & 41,00 & 39,00 & 149,67 & 266,00 & 76,67 & 141,00 & 6,00 & 7,00 & 31,00 & 37,00 & 66,43 & 64,80 \\
\hline & $1.5 \%$ & 43,00 & 41,67 & 167,67 & 350,67 & 71,33 & & 15,00 & 16,00 & 28,93 & 36,23 & 67,87 & 65,87 \\
\hline \multirow{4}{*}{$5 \mathrm{~g}$} & Zero & 35,67 & 32,67 & 159,33 & 173,67 & 62,33 & 85,67 & 9,00 & 14,67 & 25,60 & 29,23 & 19,30 & 19,87 \\
\hline & $0.5 \%$ & 41,67 & 36,00 & 163,67 & 261,33 & 82,00 & 115,33 & 11,67 & 18,00 & 27,77 & 31,07 & 27,23 & 28,33 \\
\hline & $1 \%$ & 49,67 & 40,00 & 179,33 & 283,33 & 73,00 & 113,67 & 10,00 & 11,67 & 30,30 & 34,67 & 38,13 & 39,23 \\
\hline & $1.5 \%$ & 54,67 & 52,00 & 267,67 & 294,67 & 66,00 & 130,00 & 17,00 & 20,67 & 28,70 & 30,33 & 53,33 & 54,33 \\
\hline \multirow{4}{*}{$10 \mathrm{~g}$} & Zero & 40,00 & 40,67 & 108,33 & 304,00 & 74,33 & 111,00 & 13,33 & 18,00 & 25,83 & 26,83 & 22,37 & 23,33 \\
\hline & $0.5 \%$ & 49,33 & 49,33 & 134,00 & 320,00 & 75,67 & 129,33 & 16,33 & 12,67 & 28,90 & 34,53 & 41,90 & 42,97 \\
\hline & $1 \%$ & 58,00 & 55,67 & 149,00 & 361,67 & 76,33 & 136,00 & 17,33 & 13,00 & 30,17 & 35,40 & 55,20 & 55,13 \\
\hline & $1.5 \%$ & 60,33 & 57,33 & 245,00 & 459,67 & 86,33 & 145,33 & 20,33 & 21,33 & 29,67 & 35,60 & 67,10 & 66,87 \\
\hline LSD & & 1,21 & 0,88 & 1,93 & 4,14 & 1,39 & 2,61 & 0,90 & 1,20 & 0,41 & 0,89 & 0,56 & 0,99 \\
\hline Control & & 37,67 & 35,92 & 153,17 & 267,92 & 72,50 & 131,75 & 9,50 & 12,42 & 27,93 & 34,56 & 55,54 & 55,68 \\
\hline $5 \mathrm{~g}$ & & 45,42 & 40,17 & 192,50 & 253,25 & 70,83 & 111,17 & 11,92 & 16,25 & 28,09 & 31,33 & 34,50 & 35,44 \\
\hline $10 \mathrm{~g}$ & & 51,92 & 50,75 & 159,08 & 361,33 & 78,17 & 130,42 & 16,83 & 16,25 & 28,64 & 33,09 & 46,64 & 47,08 \\
\hline LSD & & 0,75 & 0,68 & 1,35 & 1,75 & 0,93 & 1,61 & 0,50 & 0,65 & 0,28 & 0,60 & 0,09 & 0,43 \\
\hline Control & & 27,00 & 26,00 & 98,83 & 172,00 & 50,92 & 77,42 & 6,75 & 10,33 & 19,11 & 21,60 & 17,13 & 18,03 \\
\hline $0.5 \%$ oil & & 31,33 & 29,42 & 116,33 & 206,50 & 58,17 & 93,33 & 10,08 & 12,17 & 20,86 & 25,07 & 32,54 & 33,61 \\
\hline $1 \%$ oil & & 37,17 & 33,67 & 119,50 & 227,75 & 56,50 & 97,67 & 8,33 & 7,92 & 22,87 & 26,77 & 39,94 & 39,79 \\
\hline $1.5 \%$ oil & & 39,50 & 37,75 & 170,08 & 276,25 & 55,92 & 104,92 & 13,08 & 14,50 & 21,83 & 25,54 & 47,08 & 46,77 \\
\hline LSD & & 0,70 & 0,51 & 1,11 & 2,39 & 0,80 & 1,51 & 0,52 & 0,69 & 0,24 & 0,51 & 0,33 & 0.51 \\
\hline
\end{tabular}

The recorded data indicate that control treatment gave higher fungal counts than seed cake and seed oil of Nigella sativa treatments, which contain beneficial bacteria, e.g. Azotobacter chroococcum, Azospirillum brasilense, Bacillus megaterium. Similarly, Kavimandan and Gaur (1971) found that Bacillus megatherium can decompose organic phosphates and thereby improve crop yield. This may be due to the production of siderphores compounds, which inhibit fungal spore germination and increase availability of nutrients to plant and improve growth (Jagnow, 1991). Also, 
the highest total yield of cucumber plants, which were treated with seed cake and seed oil of Nigella sativa than other treatments, may be due to reductions in fruit dropping (Wilocox, 1994) and/or increases in the supply of growth hormones produced by microorganisms (Amara, 1994).

Table (14). Effect of using some biological products of (Nigella sativa L.) on yield and its component of cucumber plant during 2009/ 2010 seasons.

\begin{tabular}{|c|c|c|c|c|c|c|c|c|c|c|c|c|c|}
\hline \multicolumn{2}{|c|}{ Treatments } & \multirow{2}{*}{\multicolumn{2}{|c|}{$\begin{array}{l}\text { Fruit length } \\
\quad(\mathrm{cm})\end{array}$}} & \multirow{2}{*}{\multicolumn{2}{|c|}{$\begin{array}{c}\text { Average fruit } \\
\text { weight (g/ } \\
\text { fruit) }\end{array}$}} & \multirow{2}{*}{\multicolumn{2}{|c|}{$\begin{array}{c}\text { Total yield(g) } \\
\text { /plant }\end{array}$}} & \multirow{2}{*}{\multicolumn{2}{|c|}{$\begin{array}{l}\text { Total yield } \\
\text { (ton)/fed }\end{array}$}} & \multirow{2}{*}{\multicolumn{2}{|c|}{$\begin{array}{l}\text { Fruit diameter } \\
(\mathbf{m m})\end{array}$}} & \multirow{2}{*}{\multicolumn{2}{|c|}{$\begin{array}{c}\text { Dry matter } \\
(\%)\end{array}$}} \\
\hline \multirow{2}{*}{$\begin{array}{l}\text { Seeds } \\
\text { dregs }\end{array}$} & \multirow{2}{*}{$\begin{array}{c}\text { Seeds } \\
\text { oil }\end{array}$} & & & & & & & & & & & & \\
\hline & & S1 & S2 & S1 & S2 & S1 & S2 & S1 & S2 & S1 & S2 & S1 & S2 \\
\hline & Zero & 12,40 & 11,97 & 35,83 & 36,50 & 398,33 & 376,67 & 39,83 & 36,33 & 23,00 & 25,00 & 4,57 & 4,37 \\
\hline & $0.5 \%$ & 12,70 & 12,30 & 70,23 & 72,63 & 406,33 & 403,33 & 40,83 & 39,00 & 26,67 & 30,33 & 8,17 & 8,33 \\
\hline & $1 \%$ & 15,67 & 14,20 & 57,30 & 54,53 & 505,00 & 490,00 & 50,50 & 48,00 & 25,67 & 27,00 & 8,57 & 8,43 \\
\hline & $1.5 \%$ & 16,53 & 14,97 & 80,20 & 80,97 & 606,67 & 585,00 & 60,67 & 56,83 & 26,67 & 30,67 & 11,07 & 10,40 \\
\hline & Zero & 14,33 & 14,20 & 45,67 & 46,30 & 405,00 & 405,00 & 40,50 & 40,50 & 31,00 & 31,67 & 6,37 & 6,47 \\
\hline & $\mathbf{0 . 5 \%}$ & 13,10 & 13,80 & & 47,30 & 613, & 621,67 & 69,30 & 65,67 & 29,67 & & 7,73 & 7,23 \\
\hline 50 & $1 \%$ & 13,40 & 12,47 & 44 & 45,17 & 693,00 & 670,00 & 61,33 & 62,17 & 33,67 & 31 & 3,93 & 3,50 \\
\hline & $1.5 \%$ & 15,10 & 14,70 & & 65,00 & 798,67 & 79 & 79,87 & 77,00 & 34,33 & 0 & 7,67 & 8,03 \\
\hline & Zero & 14,10 & 15,00 & 57 & 60,23 & 500,00 & 491,67 & 50,00 & 48,17 & 32,67 & & 3,73 & 3,97 \\
\hline & $0.5 \%$ & 15,10 & 13,87 & 65,20 & 64,23 & 696,67 & 693,33 & 69,67 & 67,67 & 34,00 & 32,67 & 7,60 & 7,43 \\
\hline & $1 \%$ & 16,33 & 16,40 & 45,33 & 45,17 & 794,33 & 793,33 & 79,43 & 72,83 & 35,67 & 41,33 & 5,03 & 4,83 \\
\hline & $1.5 \%$ & 17,33 & 19,33 & 106,07 & 105,63 & 893,33 & 890,00 & 89,33 & 74,67 & 36,67 & 45,67 & 7,97 & 8,63 \\
\hline LSD & & 0,43 & & & & & & & & & & 0,54 & 0,32 \\
\hline Control & & 14,33 & 13,36 & & 61,16 & 479,08 & 463 & 47,96 & & 25,50 & 5 & 8,09 & 7,88 \\
\hline $5 \mathrm{~g}$ & & 13,98 & 13,79 & 51,55 & 50,94 & 627,50 & 622,50 & 62,75 & 61,33 & 32,17 & 35,17 & 6,43 & 6,31 \\
\hline $10 \mathrm{~g}$ & & 15,72 & 16,15 & 69,04 & 68,82 & 721,08 & 717,08 & 72,11 & 65,83 & 34,75 & 37,75 & 6,08 & 6,22 \\
\hline LSD & & 0,30 & 0,21 & 0,52 & 0,39 & 3,71 & 4,05 & 0,39 & 0,26 & 0,44 & 0,45 & 0,19 & 0,17 \\
\hline Control & & 10,21 & 10,29 & 35,27 & 35,76 & 325,83 & 318,33 & 32,58 & 31,25 & 21,67 & 22,00 & 3,67 & 3,70 \\
\hline $0.5 \%$ oi & & 10,23 & 9,99 & 45,41 & 46,04 & 429,08 & 429,58 & 44,95 & 43,08 & 22,58 & 24,83 & 5,88 & 5,75 \\
\hline $1 \%$ oil & & 11,35 & 10,77 & 36,83 & 36,22 & 498,08 & 488,33 & 47,82 & 45,75 & 23,75 & 25,00 & 4,38 & 4,19 \\
\hline $1.5 \%$ oi & & 12,24 & 12,25 & 63,98 & 62,90 & 574,67 & 567,08 & 57,47 & 52,13 & 24,42 & 29,33 & 6,68 & 6,77 \\
\hline LSD & & 0,25 & 0,27 & 0,73 & 0,66 & 4,20 & 8,42 & 0,42 & 0,58 & 0,38 & 0,80 & 0,31 & 0,19 \\
\hline
\end{tabular}

\section{CONCLUSION}

From the results obtained, it can be concluded that using Nigella sativa L., as seed cake in rates of $10 \mathrm{~g} /$ plant as soil application and 1.5\% seed oil as foliar spray to cucumber plants, improved growth and productivity of cucumber and reduced fungal diseases under North Sinia conditions.

\section{REFERENCES}

Abd El-Hafez, A.M. (1966). Some studies on acid producing microorganisms in soil and rhizosphere with special reference to phosphate dissolvers. Ph.D. Thesis, Fac. Agric., Ain Shams Univ., Cairo, Egypt.

Egyptian J. Desert Res., 62/63, 21-37 (2012/2013) 
Abd El-Malek, Y. and Y.Z. Ishac (1968). Evaluation of methods used in counting Azotobacter. J. Appl. Bacteriol., 31:267-275.

Allen, I.N. (1959). In "Experiments in Soil Bacteriology". Burgess Publishing Co., Minneapolis, Minnesota.

Amara, A.T. Mervat (1994). Wheat response to rhizosspheric bacterial inoculation under field condition. Desert Inst. Bull., Egypt, 44(2):333-355.

A.O.A.C. (1990). In "Official Methods of Analysis Association of Officinal Analytical Chemists". $16^{\text {th }}$ ed. Washington, D.C., USA.

Bettiol, W., S.A.S. Harllen and C.R. Ronielli (2008). Effectiveness of whey against zucchini squash and cucumber powdery mildew. Sci. Hortic., 117:82-84.

Bunt, J.S. and A.O. Rovira, (1955). Microbiological studies of some subontoretic soil. Journal of Soil Science, 6:119-126.

David, G. (2002). Tree Fruit Production with Organic Farming Methods. Center for Sustaining Agriculture and Natural Resources. Washington State University, Wenatchee, USA.

Dobereiner, J. (1978). Influence of environmental factors on the occurrence of Spirillum lipoferum in soil and roots. Ecol. Bull. (Stockholm), 26:343-352.

El-Dougdoug, Kh.A., Hanaa H.A. Gomaa and Rehab A. Daoud (2007). Elimination of some viruses infecting tomato plants by phytoantivirus. Research Journal of Agriculture and Biological Sciences, 3(6):994-1001, INSInet Publication.

El-Sayed, M.A.M. (2006). Effect of biofertilizers application on the productivity of Nigella saliva cultivated in desert sandy soils and efficiency of produced seeds against some pathogenic microorganisms. Ph.D. Thesis, Fac. Agric., Moshtohor, Benha Univ., Egypt.

Hafez, Y.M. (2008). Effectiveness of the antifungal black seed oil against powdery mildews of cucumber (Podosphaera xanthii) and barley (Blumeria graminis f. sp. hordei). Acta Biologica Szegediensisal, 52(1):17-25.

Harfoush, D.I. and D.A. Salama (1992). Induction of systemic resistance to powdery mildew in cucumber leaves by seed soaking application with cobalt. Ann. Agric. Sci., Mansoura Univ., 17:3555-3565.

Hassan, A. and V. Vancura (1970). Formation of biologically active substances by rhizosphere bacteria and their effect on plant growth. Microbil. Prague, 11:468-478.

Jackson, M.L. (1958). In "Soil Chemical Analysis". Prentice-Hall-Inc., Englewood Cliffs, N.J., USA. 
Jacobs, M.B. and M.J. Gerstein (1960). In 'Hand Book of Microbiology". De. Van Nostrand, Co., Inc., New York, p. 139-202.

Jagnow, G. (1991). Microbial interaction in the cereal rhizosphere. Proc. of the $32^{\text {nd }}$ Symposium of the British Ecological Sco. with the Association of Applied Biolgists, Univ. of Cambridge, 113137.

Kavimandan, S.K. and A.C. Gaur (1971). Effect of seed inoculation with Pseudomonas sp. on phosphate uptake and yield of maize. Cuar. Sci., 40:439-440.

Kiss, L. (2003). A review of fungal antagonists of powdery mildews and their potential as biocontrol agents. Pest Manage Sci., 59:475483.

Mosa, A.A. (1997). Effect of foliar application of phosphate on cucumber powdery mildew. Annals Agric. Sci., Ain Shams Univ., Cairo, 42:241-55.

Nelson, E.B., Wei Lian Chao, J.M. Norton, G.T. Nash, and G.H. Harman (1986). Attachment of Enterobacter cloaceaee to hyphae of Pythium ultima possible role in the biological of Pythium preemergence damping-off. Phytopath., 76:327-335.

Piper, C.S. (1950). In "Soil and Plant Analysis". Univ. Adelaide. Interscience Publishers. Inc. New York, p. 258-275.

Pramer, D. and E.L. Schmidt (1994). In "Experimental Soil Microbiology". Burgerss Publishing Co., Minnesota, USA, p. 235 -237.

Reuveni, M, V. Agapov and R. Reuveni (1997). A foliar spray of micronutrient solutions induced local and systemic protection against powdery mildew (Sphaerotheca fuliginea) on cucumber plants. Europen J. Plant Patho., 103:581-585.

Richards, L.F. (1954). In "Diagnosis and Improvement of Saline and Alkaline Soils". Agric., Hand Book, USA.

Sleigh, J.D. and M.C. Timburg (1981). In "Notes on Medical Bacteriology". Churchill, Livingstone, 43 pp.

Snedecor, G.W., and W.G. Cochran (1989). In "Statistical Methods". $8^{\text {th }}$ ed. Iowa State Univ. press, Iowa, USA.

Thoppil, J.E., A. Tajo and J. Minija (1998). Antibacterial and antifungal activity of four varieties of Ocimum basilicum. Fitoterapia, 69(2):191-192.

Verhaar, M.A, K.K. Ostergaard, T. Hijwegen and J.C. Zadoks (1997). Preventative and curative applications of Verticillium lecanii for biological control of cucumber powdery mildew. Biocontrol Sci. Technol., 7:543-551.

Wilocox, G.E. (1994). Effect of potassium on tomato growth and production. Proc. Hort. Sci., 85:484-489.

Egyptian J. Desert Res., 62/63, 21-37 (2012/2013) 


\title{
أثر إستخدام بعض نواتج حبة البركة المنتجة حيويًا على تحسين إنتاجية

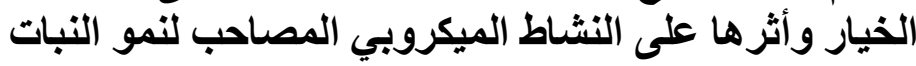

\author{
'محمود على محمد السيد " ومحمد رائف حافظ”

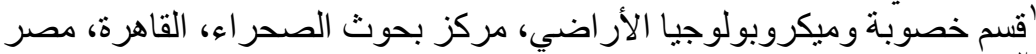

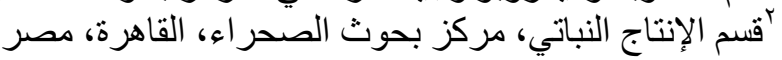

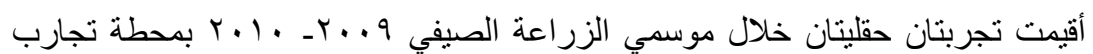

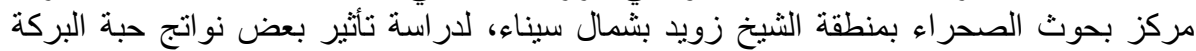

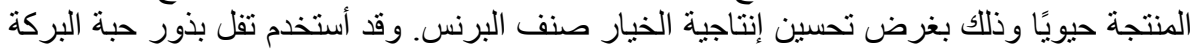

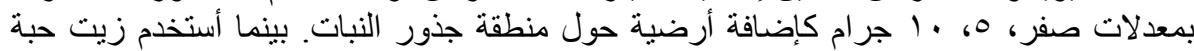

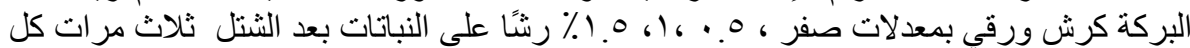
أيام.

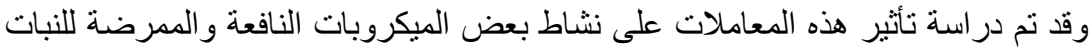

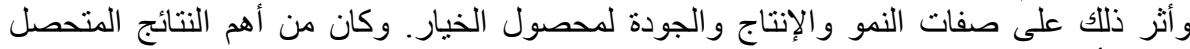

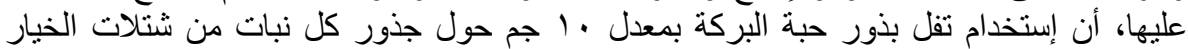

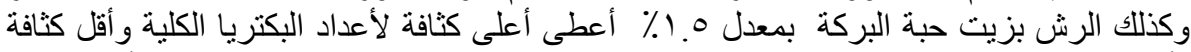

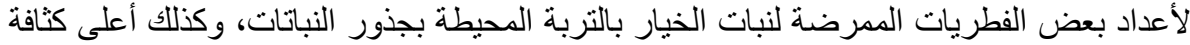

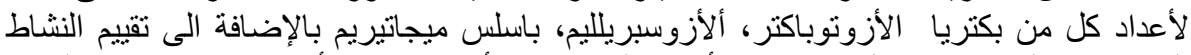

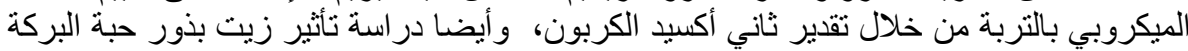

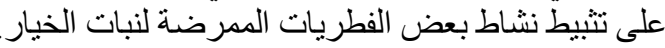

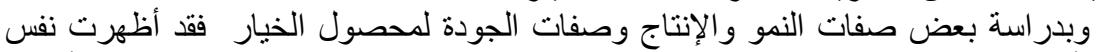

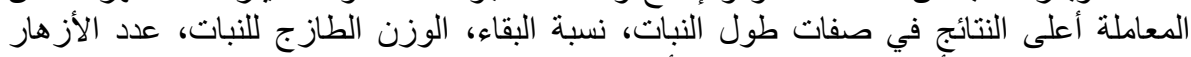

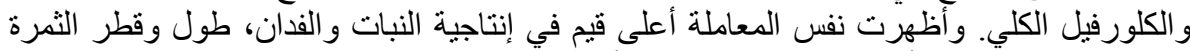
والوزن الطاز ج بينما أعطت معاملة الكنترول أعلى قيمة لصفية النسبة المئوية للمادة الجافة للنبات

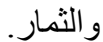


